\section{President's Comments}

$\mathrm{T}$ he end of September there was a "rerun" of a short interview about our June Salt Lake City Conference on a local television station. Immediately afterwards came two "friend requests" from old acquaintances. One I had not heard from in 30 plus years. Both were responsive to Jussi Björling, and I was again reminded of our tenor's staying power.

You will recognize staying power in each article of this Newsletter, from the newly discovered Copenhagen recital to the opera Silverfägeln, from a remastered Cavalleria and Trovatore to a new Honorary Advisor and a new member of the Board of Directors; also a famed movie star's Jussi Björling story and an old and erred movie review.

1940 was a major year for Jussi Björling. Enjoy a few photos from 75 years ago.

Jussi Björling continues to impress and demand. Taking our cue from the back cover photo, we join Mr. and Mrs. Björling in wishing you all a HAPPY THANKSGIVING and HOLIDAYS!

-Walter B. Rudolph

PS: Let me pass on this comment relating to the the July Newsletter 2015, no. 27.

Of special interest was the article about Norman Treigle. He was a fine singing actor whom we heard several times at the New York City Opera after we moved east in 1967. He and Beverly Sills were the principal stars of the company then, and one of his most important roles was Boito's Mefistofele. The only other place I heard him was San Francisco, where I attended Jussi's last Faust as discussed in the article.

I always thought Jussi had something special to bring to French roles such as Faust and Romeo, which I also heard him sing. The Faust was exciting-not only because of Jussi but because of Treigle's evil Mephistopheles and Lisitsian's Valentin. This was one of only three appearances that Lisitsian made in the U.S. He was a wonderful baritone and I wondered how and why the Cosmopolitan Opera would get such an outstanding baritone since they would usually have only one or possibly two major singers in a cast. He sang one Amonasro at the Met and gave a single NY recital. Anyway the Faust was the most memorable performance of that opera that I have seen.

Best regards, Harry Glaze continued from front cover

Just to whet your appetite for this CD, here is the program of that evening: Jussi warms up with Tamino's Act 1 aria from Die Zauberflöte, 'Dies Bildnis', sung in Swedish. He then takes on Lieder by Brahms ("Die Mainacht"), Liszt ("Es muss ein Wunderbares sein") and Wolf ("Verborgenheit"). Then we have two contrasting Lieder by Schubert, "Die Forelle" and "Die böse Farbe", and the Carmen "Flower Song." Next come two little Swedish songs, "Jungfrun under lind" and "Skogen sover," followed by the Sibelius songs "Demanten på marssnön" and "Säv, säv, susa" and the pair of Grieg songs "En svane" and "En drøm." The program concludes with three Björling favorites, "Come un bel dì di Maggio" from Andrea Chénier, Tosti’s "Ideale," and R. Strauss's "Zueignung."

There is much beautiful music here, and one's concern is of Jussi's health during this period: we know that during late September, 1959, our tenor was in Rome recording Butterfly, and that he collapsed while singing the love duet. But from several samples we have heard from the October 15 concert, Jussi's vocalism is in top form again: We look forward to hearing the final CD of the whole program, on our own equipment, soon! *

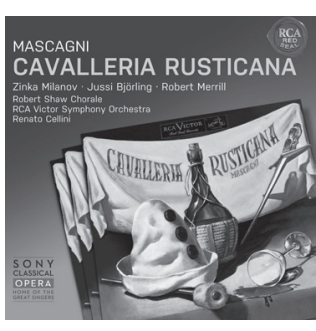

Mascagni:

\section{Cavalleria rusticana}

Sony/RCA has reissued the 1953 Björling/ Milanov/Merrill Cavalleria rusticana. The remastering is done by John Fredenburg from the original RCA tapes. Andy Pope reports excellent (sound) with Björling at his silvery best, the magnificent Milanov in her absolute prime and Merrill with his beautiful baritone; a must to have in very fine sound.

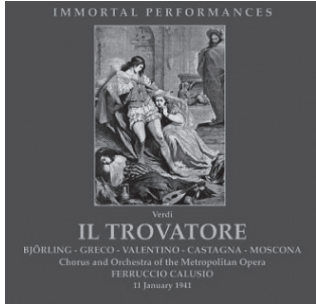

\section{Verdi: Il trovatore}

Björling, Greco, Castagna, Valentino, Calusio (con). This thrilling performance presents the January 11, 1941 Björling Met broadcast in vastly improved sound with commentary by Milton Cross, remastered by Richard Caniell for Immortal Performances. The notes are by Stephen Hastings. Also included are biographies and recording notes plus rare photos. A bonus is the Björling March 10, 1952 Firestone Broadcast. (2 CDs). 